\title{
Article \\ Morphological Study of Bio-Based Polymers in the Consolidation of Waterlogged Wooden Objects
}

\author{
Zarah Walsh-Korb ${ }^{1, *, t, \ddagger}$, Ingrid Stelzner ${ }^{2,3, \S \mathbb{D}}$, Juliana dos Santos Gabriel ${ }^{1,4}$, Gerhard Eggert ${ }^{2} \mathbb{D}$ \\ and Luc Avérous 1,*(D)
}

Citation: Walsh-Korb, Z.; Stelzner, I.; dos Santos Gabriel, J.; Eggert, G.; Avérous, L. Morphological Study of Bio-Based Polymers in the Consolidation of Waterlogged Wooden Objects. Materials 2022, 15, 681. https://doi.org/10.3390/ ma15020681

Academic Editor: Federico Cerrone

Received: 7 December 2021

Accepted: 10 January 2022

Published: 17 January 2022

Publisher's Note: MDPI stays neutral with regard to jurisdictional claims in published maps and institutional affiliations.

Copyright: (C) 2022 by the authors. Licensee MDPI, Basel, Switzerland. This article is an open access article distributed under the terms and conditions of the Creative Commons Attribution (CC BY) license (https:// creativecommons.org/licenses/by/ $4.0 /)$.
1 BioTeam/ICPEES-ECPM, UMR CNRS 7515, Université de Strasbourg, 25 rue Becquerel, CEDEX 2, 67087 Strasbourg, France; jugabriel.contato@gmail.com

2 Staatliche Akademie der Bildenden Künste Stuttgart, Am Weißenhof 1, 70191 Stuttgart, Germany; ingrid.stelzner@rgzm.de (I.S.); gerhard.eggert@abk-stuttgart.de (G.E.)

3 Landesamt für Denkmalpflege im Regierungspräsidium Stuttgart, Berliner Straße 12, 73728 Esslingen am Neckar, Germany

4 Department of Physical Chemistry, University of São Paolo, IQSC-USP, São Carlos 13560-970, Brazil

* Correspondence: zarah.korb@unibas.ch (Z.W.-K.); luc.averous@unistra.fr (L.A.)

+ Current address 1: Laboratory for Molecular Engineering of Synthetic Systems, Department of Chemistry, Universität Basel, Mattenstrasse 24a, 4058 Basel, Switzerland.

$\ddagger$ Current address 2: Department of Biosystems Science and Engineering, ETH Zurich, 8092 Zurich, Switzerland.

$\S$ Current address: Römisch-Germanisches Zentralmuseum Mainz, Ernst-Ludwig-Platz 2, 55116 Mainz, Germany.

\begin{abstract}
The removal of water from archaeological wooden objects for display or storage is of great importance to their long-term conservation. Any mechanical instability caused during drying can induce warping or cracking of the wood cells, leading to irreparable damage of the object. Drying of an object is commonly carried out in one of three ways: (i) air-drying with controlled temperature and relative humidity, (ii) drying-out of a non-aqueous solvent or (iii) freeze-drying. Recently, there has been great interest in the replacement of the standard, but limited, polyethylene glycol with biopolymers for wood conservation; however, their behaviour and action within the wood is not completely understood. Three polysaccharides-low-molar-mass $\left(\mathrm{M}_{w}\right)$ chitosan $\left(\mathrm{M}_{w}\right.$ ca. $60,000 \mathrm{~g} / \mathrm{mol})$, medium-molar-mass alginate $\left(\mathrm{M}_{w}\right.$ ca. $\left.100,000 \mathrm{~g} / \mathrm{mol}\right)$ and cellulose nanocrystals (CNCs)-are investigated in relation to their drying behaviour. The method of drying reveals a significant difference in the morphology of these biopolymers both ex situ and within the wood cells. Here, the effect these differences in structuration have on the coating of the wood cells and the biological and thermal stability of the wood are examined, as well as the role of the environment in the formation of specific structures. The role these factors play in the selection of appropriate consolidants and drying methods for the conservation of waterlogged archaeological wooden objects is also investigated. The results show that both alginate and chitosan are promising wood consolidants from a structural perspective and both improve the thermal stability of the lignin component of archaeological wood. However, further modification would be necessary to improve the biocidal activity of alginate before it could be introduced into wooden objects. CNCs did not prove to be sufficiently suitable for wood conservation as a result of the analyses performed here.
\end{abstract}

Keywords: freeze-drying; waterlogged wood; natural polymers; structure; archaeology; conservation

\section{Introduction}

A large number of artefacts of cultural importance are organic in nature [1], of which wood is a particularly common, but highly important, material [2]. The degradation processes of many of these artefacts have been influenced by waterlogged environments, for example, lacustrine pile dwellings, means of transportation, tools or war and trading ships, such as the 16th century warship Mary Rose, the 17th century warship Vasa and the 
Etruscan harbour ships [3-8]. The waterlogged, mainly anoxic environments, from which they are excavated, do a remarkable job in preserving these objects for many centuries [9]. Upon excavation, however, problems begin to appear. Apart from mechanical damage, the combination of an oxygenated atmosphere and water within the wood provide an ideal environment for the rapid proliferation of bacteria and fungi, as well as chemical modes of degradation [10-13]. Drying of the object is, therefore, extremely important for long-term preservation efforts; however, dimensional instability during drying is often a major concern. When bound water is removed from the cell wall, shrinkage of the wood can occur. The development of contractile capillary forces during natural air-drying can lead to collapse of the degraded wooden structure [14]; thus, methods such as solvent-drying, freeze-drying and supercritical drying have been investigated [15-20]. To avoid shrinkage of the wood and strengthen the degraded object, free water is often exchanged for an aqueous polymer solution, typically poly (ethylene glycol) (PEG). The higher molar mass and much lower vapour pressure of PEG compared to water allows it to remain in the wood cells during drying [21]. In recent years, much work has been carried out examining the long-term behaviour of this common wood consolidant [15,22]. Mortensen et al. [21] observed that the natural aging of PEG produces formic acid, which exacerbates degradation of the acid-sensitive cellulose and holocellulose within the wood. Almkvist and Persson found that the formation of acidic by-products was accelerated by the presence of $\mathrm{Fe}^{3+}$ ions in the wood from degraded iron bolts and fastenings [23,24]. Moreover, mechanical instability during the period of display can also be problematic [25-27]. Bardet et al. [28-30] and Bjurhager et al. [4] observed that the use of high concentrations of hygroscopic lowmolar-mass PEG consolidants could, over time, lead to plasticisation and deformation of wood cells [31].

These discoveries resulted in great interest in the development of alternative consolidants, mainly bio-based and biopolymer systems [26,27,32-37]. According to IUPAC, biopolymers can be defined as polymers directly extracted from biomass, such as proteins or polysaccharides [38]. While bio-based polymers have been extracted from natural resources, they have been modified, resulting in a composition that is not directly found in nature. Ultimately, the use of bio-based polymers and biopolymers is seen as a way to limit the use of fossil-based polymers with potentially damaging degradation from by-products. For simplicity, the term biopolymer will be used throughout the text, although chitosan, the deacetylated form of chitin, is technically a bio-based polymer rather than a biopolymer.

Recently, links have also been drawn between the overall weight of the consolidant within the wood and its long-term mechanical stability, indicating that mechanical failures due to excessive strain on weakened timber increase with increasing consolidant weight [25]. Although the molar mass of many potential biopolymer treatments is significantly higher than PEG, the amount of biopolymer needed to produce the same mechanical response is often dramatically lower. Walsh et al. showed that similar rheological properties can be obtained from solutions of biopolymers at $0.5-1 \mathrm{wt}$ \% as well as for PEG solutions of approx. $50 \mathrm{wt}$ \% [27]. Thus, overall reduced consolidant weight is a particular advantage of biopolymer treatments. However, the behaviour of these biopolymers in situ, their structure upon drying, an important factor for evaluating future re-treatability [35], and their biological resistance, a requirement for their applicability [15], were not examined.

Research has also shown that the efficient removal of free water from wood, and the method by which it is removed, also contribute to long-term stability. Freeze-drying has become a key technique for the gentle and controlled removal of water, as the wood is maintained in a frozen state while water is sublimed from the structure, avoiding cell wall collapse. The combination of freeze-drying with a consolidant that replaces water and bulks the remaining wood cells, which acts as a cryoprotector during freezing but does not sublime, further reduces damage. The majority of studies on drying behaviour in the presence of consolidants have focused on PEG and the effect of the freeze-drying conditions only [39-45]. However, conservation of waterlogged wooden and non-wooden objects with the bio-based polymer Klucel (hydroxypropylcellulose, $\mathrm{M}_{w}=80,000 \mathrm{~g} / \mathrm{mol}$ ) has been 
reported and has recently shown its applicability and suitability, as well as that of a range of other alternative polymers, to the freeze-drying process [46-48]. Concerns about the susceptibility of cellulose-based consolidants to the same degradation issues as the wood itself may, however, be an issue for their widespread application [27,32]. Moreover, the high molar masses of these biopolymers could retard their diffusion into the wood, which has been observed in the treatment of beech spatulas with Klucel EF [48] and archaeological oak with chitosan [34]. Experiences from the conservation of wooden objects reveal many examples where only the hull is consolidated but not the core, resulting in fragility [49].

As mentioned previously, solution concentrations of biopolymers are often significantly lower than PEG solutions, which can overcome issues of viscosity during treatment, as seen in Table 1 (experimental section), but leads to concerns over the density of the treatment within the wood.

Table 1. Measured viscosity of the polymers used in this work, all measurements recorded at $25^{\circ} \mathrm{C}$.

\begin{tabular}{ccc}
\hline Polymer & Concentration (wt. $\%)$ & Viscosity $\left(\mathbf{m m}^{\mathbf{2}} / \mathbf{s}\right)$ \\
\hline PEG $(400 \mathrm{~g} / \mathrm{mol})$ & 50 & 11.27 \\
Sodium alginate $(100,000 \mathrm{~g} / \mathrm{mol})$ & 1 & 68.68 \\
Chitosan $(60,000 \mathrm{~g} / \mathrm{mol})$ & 1 & 12.62 \\
CNCs $(5 \mathrm{~nm} \times 100 \mathrm{~nm})$ & 1 & 1.95 \\
\hline
\end{tabular}

However, in biomass, organisation tends to play the major role in the mechanical properties with many examples of strong and mechanically adaptable systems, where organisation within the structure contributes to exquisite mechanical properties, e.g., nacre, bone, teeth and wood itself [50]. Recent literature has also highlighted the usefulness of controlled drying techniques in the preparation of polysaccharide-based aerogels designed to mimic the high mechanical strength of biomaterials [51]. Thus, it is supposed that the structure of the polymer after drying, in addition to its molar mass, would affect the mechanical properties of the treated wood, much in the way structuration of proteins and biopolymers dictate the strength and stability of many aspects of biomass. The structure of the consolidant can also play a major role in the long-term preservation of archaeological objects, as only open, porous structures can be re-treated and allow future consolidants to penetrate the artefact [34].

In this preliminary study, the drying behaviour and thermal and biological stability of selected biopolymers, as well as biopolymer-treated archaeological wood under different drying conditions, is presented to better understand the role of consolidant structuration in the long-term stability of waterlogged wooden artefacts. The effect of the wood environment on the drying behaviour is also examined. Originally, interest was confined to chitosan and cellulose nanocrystals in accordance with the past literature [34,52]; however, a recent publication by Janeček et al. [53] indicated an enhanced diffusion of negatively charged polymers within the wood cells; thus, alginate, a negatively charged polysaccharide, was also investigated.

\section{Materials and Methods}

\subsection{Materials}

Poly (ethylene glycol) (PEG, $\left(\mathrm{M}_{w}=400 \mathrm{~g} / \mathrm{mol}\right)$, chitosan $\left(\mathrm{M}_{w}=60,000 \mathrm{~g} / \mathrm{mol}\right)$, silicon wafers, agar, Müller-Hinton lysogeny broth, glycerol and acetic acid were all obtained from Sigma-Aldrich Chemical Company (St. Quentin Fallavier, France) and used as received. Alginate $\left(\mathrm{M}_{w}=100,000 \mathrm{~g} / \mathrm{mol}\right)$ was donated by FMC Chemical International AG (Dublin, Ireland) and used as received. Cellulose nanocrystals ( $\mathrm{L}=100 \mathrm{~nm}, \mathrm{~d}=5 \mathrm{~nm}$ ) were kindly provided by CelluForce (Montréal, Canada). Both fresh and archaeological waterlogged oak wood (Quercus robur) used in this work was obtained from the Mary Rose Museum, for dimensions see electronic supplementary information (Appendix A). Non-pathogenic Escherichia coli (E. coli, DSM 5451-0599-001) and Bacillus subtilis (B. subtilis, DSM-1970-0110-001) were purchased from the German Collection of Microorganisms and 
Cell Cultures (DSMZ) GmbH (Braunschweig, Germany). Liquid nitrogen for cryogenic freezing was obtained from Kraiss \& Friz e.K., (Remshalden, Germany). Water used in all experiments was obtained from an in-house water deionisation system. Preparation of films for initial microscopy studies and treatment of the wood samples is detailed in Appendices A.1 and A.2. Protocols for the biological tests are given in Appendix A.3.

\subsection{Instrumentation}

Standard light microscope images of polymer films were taken on a DM 750 Light Microscope from Leica Microsystems GmbH (Wetzlar, Germany). Determination of the freeze-drying ability of the biopolymer solutions was carried out on a freeze-drying microscope (FDM). The FDM comprised a transmitted light-polarising microscope (Axio Scope. A1, Carl Zeiss Microscopy Deutschland GmbH, Oberkochen, Germany) with a Lambda plate (polariser $\mathrm{D}, 90^{\circ}$ pivotable, disengageable) and a freeze-drying stage (FDCS 196, Linkam Scientific instruments Ltd., Tadworth, UK), which can be cooled with liquid nitrogen and evacuated with a vacuum pump (Ilmvac GmbH, Ilmenau, Germany). The pressure was controlled using a Pirani gauge. A digital camera recorded images, which were analysed using Linksys 32 software (Linkam Scientific instruments Ltd., Tadworth, UK). Bulk freeze drying was carried out in an Alpha 2-4 LDPlus lyophiliser (Martin Christ, Osterode am Harz, Germany) for 2-3 h, where the pressure of the condenser was 0.01 mbar, and the temperature was $-86^{\circ} \mathrm{C}$. Scanning electron microscope (SEM) images were obtained using a Vega 3 LM SEM (TESCAN, Brno, s.r.o., Czech Republic) at an accelerating voltage of $5 \mathrm{keV}$ and a working distance of ca. $11 \mathrm{~mm}$. Samples were coated with a gold layer 10-20 nm thick using a Q150R S sputter-coater (Quorum Technologies Ltd., Lewes, UK) prior to analysis. Thermal analysis of the treated samples was carried out on a Q200 thermogravimetric analyser from TA Instruments with a temperature ramp of $20-500{ }^{\circ} \mathrm{C}$ at $10{ }^{\circ} \mathrm{C} / \mathrm{min}$. Biological tests were carried out at $37^{\circ} \mathrm{C}$ in either an Infors AG (Bottmingen, Switzerland) Type 225 agitator/incubator at $200 \mathrm{rpm}$ for solution-based tests or a static incubator for plate-based tests for $18 \mathrm{~h}$.

\subsection{Freeze-Drying Protocol}

To determine the suitability of the chosen biopolymers for freeze-drying applications, a drop of a $1 \mathrm{wt} . \%$ solution of each tested polymer was placed on a glass slide inside the chamber of a freeze-drying microscope. The samples were subjected to a temperature ramp from room temperature to $-40{ }^{\circ} \mathrm{C}$ at $10{ }^{\circ} \mathrm{C} / \mathrm{min}$ and held at this point for $8 \mathrm{~min}$. The samples were then heated from $-40{ }^{\circ} \mathrm{C}$ to $-20^{\circ} \mathrm{C}$ at $10{ }^{\circ} \mathrm{C} / \mathrm{min}$ and then further from $-20^{\circ} \mathrm{C}$ to $0{ }^{\circ} \mathrm{C}$ at $1{ }^{\circ} \mathrm{C} / \mathrm{min}$ with a pressure of $15 \mathrm{~Pa}$ where freeze-drying took place.

\section{Results and Discussion}

\subsection{Freeze-Drying Behaviour of Chitosan, Alginate and CNCs}

Controlled drying of waterlogged wood after treatment with a consolidant is often crucial to ensuring its prolonged dimensional stability. Thus, before examining the structuration of air-dried and freeze-dried polymers, it was necessary to optimise the freeze-drying conditions of each of the biopolymers and compare these with the state-ofthe-art PEG consolidant. Previous experiments by Jensen and Schnell [54] and Wiesner and Giesler [39] have shown that PEG with $\mathrm{M}_{w} \leq 1500 \mathrm{~g} / \mathrm{mol}$ does not freeze in standard commercial freeze-driers, as temperatures below $-35^{\circ} \mathrm{C}$ (the standard temperature cutoff) are required to ensure PEG remains frozen during drying. Between $1500 \mathrm{~g} / \mathrm{mol}$ and $10,000 \mathrm{~g} / \mathrm{mol}$ the solid temperature is in the region of $-17^{\circ} \mathrm{C}$, making them suitable for freeze- drying applications. Low temperatures also extend the drying time, which is of particular importance for large objects. As mentioned previously, determining the freezing point of the polymer is important in preventing the consolidant from melting and losing any structuration before drying. The determination of the freezing point of each of the biopolymers found that at $-19.4,-15.0$ and $-12.6{ }^{\circ} \mathrm{C}$ for chitosan, $\mathrm{CNCs}$ and alginate, respectively, structuration was observed throughout the sample, and this was taken to be 
the freezing point. It can, therefore, be seen that both alginate and CNCs fall into the same freezing point range as the 1500-10,000 g/mol PEG solutions, while chitosan is slightly lower, although well within the same range. The freezing and sublimation for all three biopolymers are shown in Figure 1.

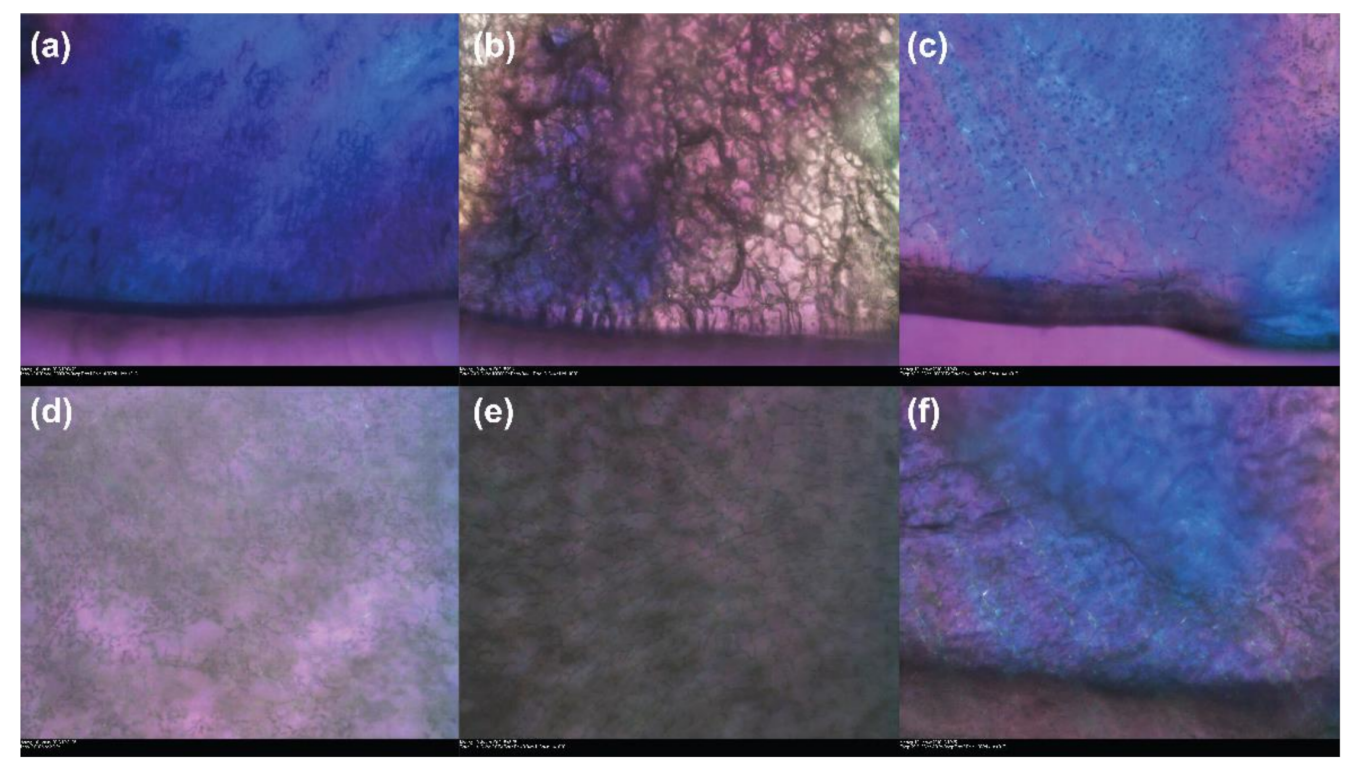

Figure 1. Images taken directly after freezing $(\mathbf{a}-\mathbf{c})$ and during freeze-drying $(\mathbf{d}-\mathbf{f})$ with a freezedrying microscope of $1 \mathrm{wt}$.\% solutions of chitosan $(\mathbf{a}, \mathbf{d})$, alginate $(\mathbf{b}, \mathbf{e})$ and cellulose nanocrystals $(\mathbf{c}, \mathbf{f})$, magnification $65 \times$.

The freezing of alginate produces an open, porous structure characterised by thick alginate fibres and large pores (Figure 1a), which remains intact during the sublimation of water (Figure 1d). Heating the sample slowly during sublimation allowed the determination of the range over which freeze-drying was possible without melting the alginate. Evidence of sublimation was observed from $-14.9^{\circ} \mathrm{C}$ up to complete drying at $-11.5^{\circ} \mathrm{C}$ with no evidence of melting or collapse of the porous network structure. Chitosan (Figure 1b,e) displayed a more densely interlinked network structure with smaller fibres and pores (Figure 1b), which remains in the dried polymer (Figure 1e). Sublimation began at approx. $-17.9^{\circ} \mathrm{C}$ and all water was removed by $-9.9^{\circ} \mathrm{C}$. However, some melting of the sample structure was observed around $-12{ }^{\circ} \mathrm{C}$ (Appendix A Figure A1), indicating that the sublimation must take place below this temperature to avoid structural changes. Such ranges of drying behaviour without melting are important for the drying of larger objects, where maintaining the same, precise temperature throughout the object is more difficult.

The behaviour of the CNCs was slightly different to that observed for alginate and chitosan (Figure 1c,f). Upon freezing, CNCs form an ordered crystalline structure on the glass surface due to the strong H-bonding between them in solution (Figure 1c); this structure remains after the drying of the sample (Figure 1f). Interestingly, instead of displaying a drying front, as for alginate and chitosan, CNCs appear to instantaneously sublime after $-15^{\circ} \mathrm{C}$, and a completely dry sample was observed at $-14^{\circ} \mathrm{C}$. It is interesting to note that, as the perceived crystallinity of the biopolymers increases, the drying range of the samples decreases in the order chitosan $>$ alginate $>$ CNCs. This is potentially very useful for the future development of tailored consolidant systems, such as those described by Walsh et al. [26]. Greater control over the organisation and interactions of chains within the consolidant through chemical modifications giving rise to specific physical or covalent interactions between biopolymer chains could lead to better, more rapid freeze-drying and a greater chance of locking-in specific architectures within wood, leading to better stabilising mechanisms. Examination of the freeze-drying behaviour of the polymers has confirmed their suitability for the freeze-drying process and highlighted the unique structures formed 
by freezing of the polymers prior to drying. Considering many natural materials obtain their mechanical strength from the specific orientation of their component particulates and polymeric chains, such in situ structuration should influence the mechanical properties of the wood; an in-depth investigation on this is ongoing.

\subsection{Comparison of Polymer Structure as a Function of Drying}

3.2.1. Drying Ex Situ

Initial optimisation of the freeze-drying conditions of $1 \mathrm{wt}$ \% solutions of alginate, chitosan and CNCs showed that the freeze-drying conditions were similar to those previously reported for PEG. Large variation was, however, observed as a function of crystallinity. The freeze-drying microscope images also indicated a structuration of the consolidants during the drying process.

While it is clear that structuration within the wood would be influenced by the structure of the wood cell and the chemical interactions between the wood and the consolidant, it is still important to examine the basic structuration of the polymer outside of the wood to better understand structuration of the consolidant as a general function of drying. In order to probe the effect of drying, samples of polymers were prepared on silicon wafers for analysis by scanning electron microscopy (SEM). In addition to freeze-dried samples of the selected solutions prepared en masse in a lyophiliser, in place of the microscope stage, air-dried samples were prepared to observe structural differences as a result of drying. The results of this experiment were analysed by SEM and are shown in Figure 2.

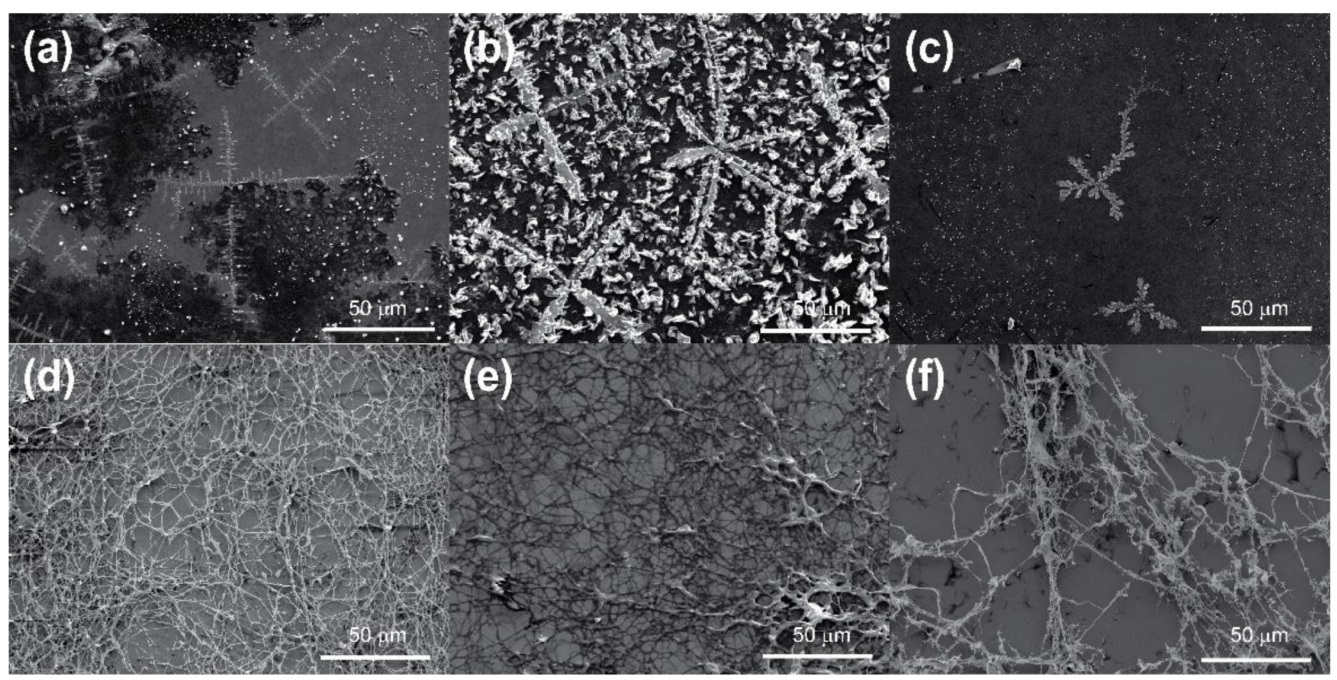

Figure 2. Scanning electron micrographs of $0.1 \mathrm{wt}$.\% air-dried solutions of (a) chitosan, (b) alginate, (c) CNCs and $0.1 \mathrm{wt} . \%$ freeze-dried solutions of (d) chitosan, (e) alginate and (f) CNCs, magnification $1.38 \mathrm{k} \times(\mathbf{a}-\mathbf{c}), 890 \times(\mathbf{d}-\mathbf{f})$.

The SEM images illustrate a rather remarkable difference between the structure of airdried (Figure $2 \mathrm{a}-\mathrm{c}$ ) and freeze-dried (Figure $2 \mathrm{~d}-\mathrm{f}$ ) polymers. In each of the air-dried samples a thin film was formed, which on closer inspection had a random crystalline/amorphous appearance. The quantity of the crystalline domains appeared somewhat dependent on the crystalline content of the polymer, in that chitosan (being mainly amorphous) showed far fewer crystalline regions than alginate or CNCs, which have a higher degree of crystallinity. In examining the freeze-dried structures, it can be seen that all three polymers displayed an open network structure. This has been reported previously by Christensen et al. [34] for chitosan and cellulose nanowhiskers and was, therefore, to be expected. Such structuration of the polymers is extremely interesting. It is assumed that when dried in situ the air-dried polymers form wall coatings, while the freeze-dried polymers form network structures on or within the wood cells. From the point of view of wood conservation, network structures are the more desirable outcome. When wood cells are coated with polymer, but the polymer 
does not completely fill the lumen, there is the potential that cells collapse under mechanical stress as there is insufficient support from the consolidant. Network structures within the lumen have the advantage of being able to bridge the empty space, allowing the cells to better respond to and potentially offset mechanical stress, improving the mechanical stability of the structure, similarly to how mass transfer across the hierarchical structure of wood itself gives it its exquisite mechanical properties [55].

\subsubsection{Polysaccharide Treatment of Whole Wood Samples}

To examine this further, samples of archaeological wood of approx. $0.8 \mathrm{~cm} \times 0.5 \mathrm{~cm} \times$ $0.5 \mathrm{~cm}$ were treated with chitosan, alginate and CNCs over 14 weeks, dried and examined again by SEM, as seen in Figure 3.

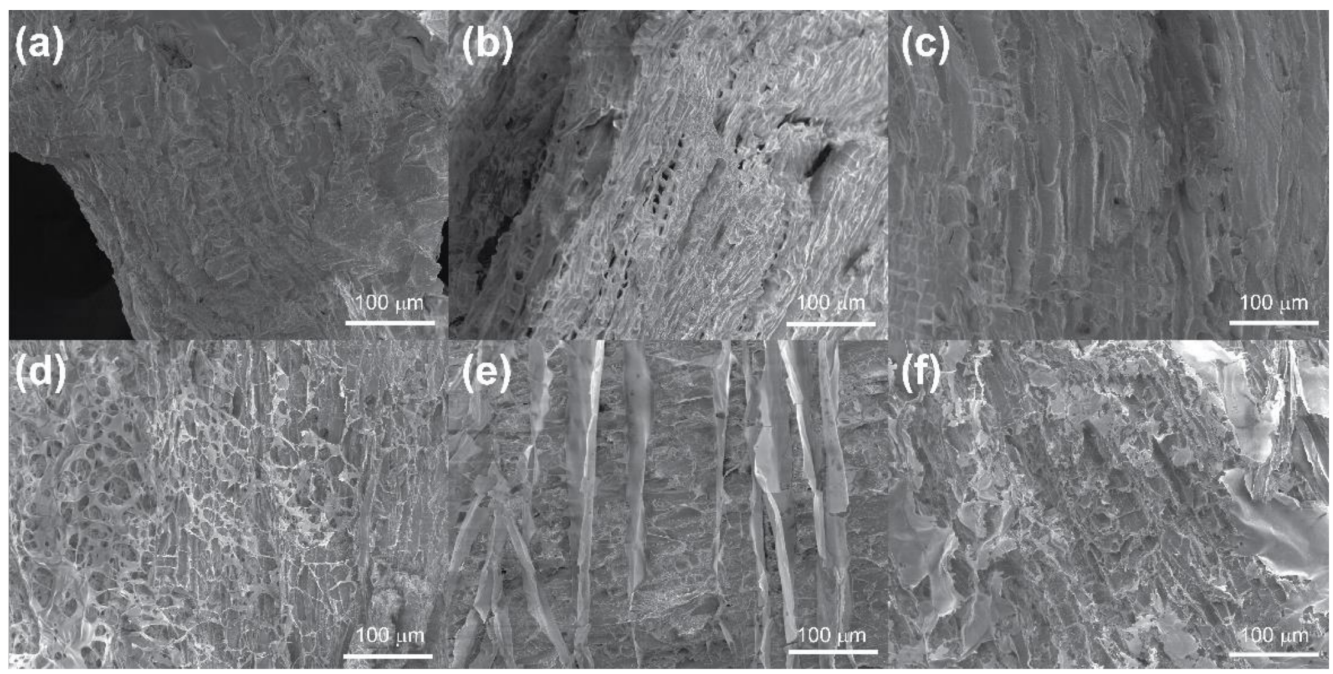

Figure 3. Scanning electron micrographs of archaeological wood with $0.5 \mathrm{wt}$.\% air-dried solutions of (a) chitosan, (b) alginate, (c) CNCs and $0.5 \mathrm{wt}$ \% freeze-dried solutions of (d) chitosan, (e) alginate and (f) CNCs, magnification $554 \times$.

As expected, the air-dried samples appeared to have no polymer coating. However, visual observation of a shiny coating on the surface of the wood confirmed the presence of the biopolymer coating. On the other hand, freeze-dried samples dried were visibly coated with the open, porous network observed in Figure 3d-f. In the case of chitosan and CNCs this structure appeared random, although similarities between the network and structure of the wood cells could be seen and seemed to form independently of the cell wall. In the case of alginate, however, the structuration closely followed the natural pattern of the wood, indicating a polymer-wood adhesion effect. Such behaviour poses the question of whether alginate is more adhesive to the wood structure than chitosan or CNCs as a function of surface chemistry or charge, as mentioned previously by Janeček et al. [53].

\subsubsection{Drying Behaviour in the Wood Cells}

Large-scale treatment poses certain issues related to molar mass and diffusion within the wood and makes interpretation of the in situ behaviour more complex. To simplify these observations, thin layers (ca. $10 \mu \mathrm{m}$ ) of both fresh and archaeological wood were cut using a microtome. Fresh wood was used in this case as a control to better understand polymer interactions with the cell walls. These pieces were then immersed in distilled water for approx. 10 months, ensuring complete waterlogging. The wood was removed from distilled water, immersed in $0.5 \mathrm{wt}$.\% solutions (to reduce sample viscosity) of CNCs, chitosan or alginate for $30 \mathrm{~h}$ and, finally, subjected to air-drying or bulk freeze-drying. The results of SEM investigation of both the archaeological and fresh wood are shown in Figure 4. 


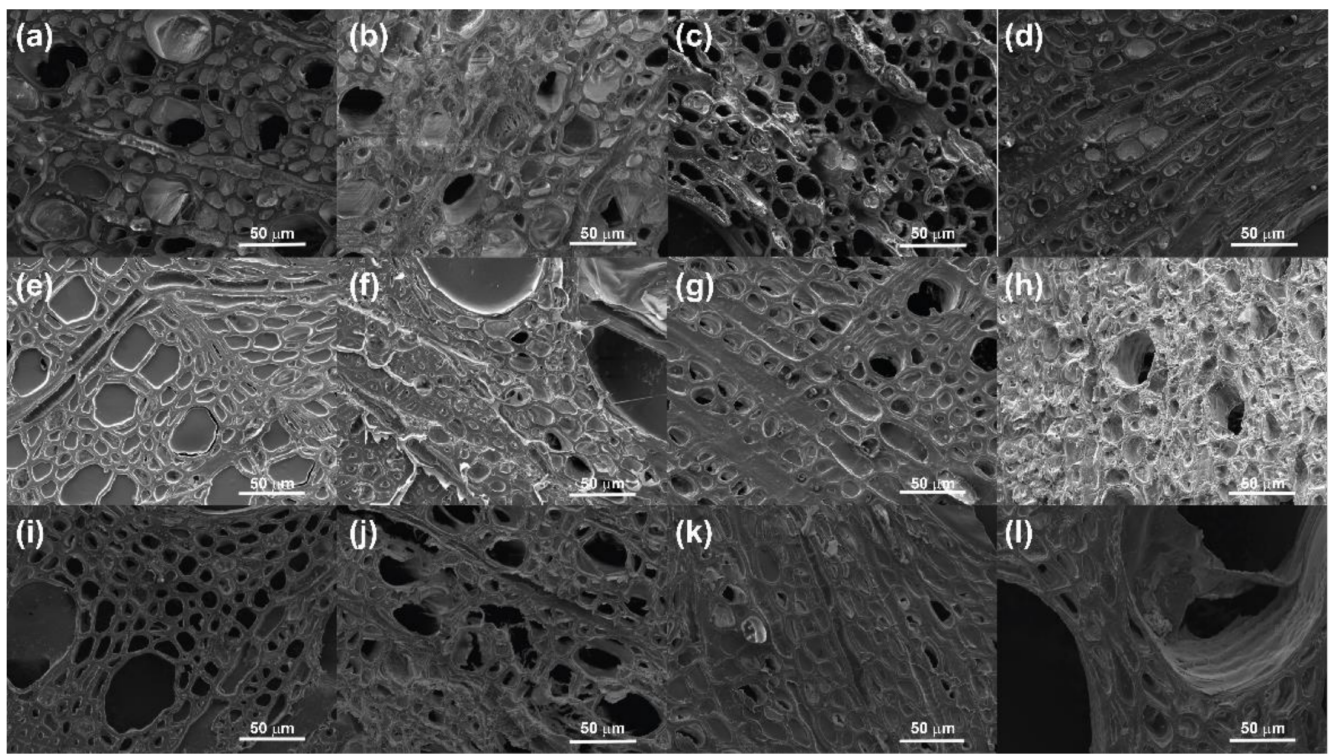

Figure 4. Scanning electron micrographs of chitosan-treated fresh wood after air- (a) and freezedrying (b) and archaeological wood after air- (c) and freeze-drying (d); alginate-treated fresh wood after air- (e) and freeze-drying (f) and archaeological wood after air- (g) and freeze-drying (h); and CNC-treated fresh wood after air- (i) and freeze-drying $(\mathbf{j})$ and archaeological wood after air- $(\mathbf{k})$ and freeze-drying (1), magnification $1.11 \mathrm{k} \times$.

While Figure 3 suggests it can be difficult to verify the presence of the air-dried polymers within the wood cells, by cutting the samples into thin sections before treatment, so that the cells, lumens and pits are visible, the mode of attachment of the polymers to the cells was more evident. Figure $4 a-d$ show sections of chitosan-treated fresh (Figure 4a,b) and archaeological (Figure 4c,d) wood after air- and freeze-drying. Both air- and freezedried samples (Figure $4 a-d$, respectively) were markedly different. Chitosan-treated airdried fresh oak appeared to leave no visible coating and little filling of cells and lumens, although it is likely from visual observation that a thin film covered the wood, while the archaeological oak showed coverage by a thick network, which could be seen protruding from the cells. These protrusions may have been damage due to the vacuum of the SEM, suggesting that the films may not be very mechanically stable. In the case of the freezedried fresh oak, there was significant structured polymer observed both with the cells and lumen and along the secondary cell wall structure. A similar pattern was observed with the archaeological oak, although to a lesser extent, indicating the possibility that cell wall components to which the chitosan will attach are reduced during waterlogging or degradation. Another potential explanation is that the chemical structure of chitosan is heavily dependent on the environment, which may interrupt the formation of network structures, instead allowing only film-like coatings that are difficult to observe in the SEM.

The alginate-treated wood (Figure $4 \mathrm{e}-\mathrm{h}$ ) showed even better uptake of the polysaccharide at the same concentration and over the same treatment duration. Both fresh (Figure 4e) and archaeological (Figure 4g) air-dried samples showed significant film formation in the cells, lumen and pits. The number of filled cells in the archaeological oak was slightly reduced compared to the fresh wood, which may have been due to natural wood variation or the leaching of extractives to which alginate may bind, thus reducing its affinity for the cell wall. The freeze-dried samples of fresh (Figure 4f) and archaeological (Figure 4h) showed a similar pattern of filling. The fresh oak showed a mixture of film formation and structuration of the alginate both within the cells and along the cell wall. The structuration of the alginate in the environment of the archaeological oak was much more pronounced. Figure $4 \mathrm{~h}$ showed that almost every cell was filled with a randomly structured network that also followed the cell wall structure above the wood. From this specific behaviour, it can be assumed that alginate is not only a suitable consolidant due to its ability to form a 
network structure within the wood cells but also because it creates structure where there is no template. This suggests it may also be suitable for gap-filling in the wood morphology with a network that strongly mimics that of the "missing" wood.

Lastly, Figure 4i-1 show images of wood treated with CNCs. As with the air-dried samples of chitosan and alginate, film formation could be observed in both the fresh (Figure 4i) and archaeological (Figure 4k) samples. As seen in chitosan-treated samples, the film formation seemed more extensive in the archaeological rather than the fresh sample; however, as before, this might have been due to natural variation or the affinity of the CNCs for the cell wall after removal of extractives. The freeze-dried samples showed a similar tendency, with lots of structured networks visible along the cell wall and within some cell lumen in the fresh oak, although less than observed for chitosan, (Figure 4j), and some film formation and structuration was visible in the archaeological oak (Figure 4l), although, again, to a reduced degree. The treatment of the wood with the biopolymers certainly produced some interesting results and avenues for further study. It would appear from the SEM images that the alginate fills the wood cells better within the treatment window compared to the solutions of chitosan and CNCs. This is completely at odds with their molar masses and the dimensions of the CNCs, as well as the apparent viscosity of the solutions, as given in Table 1.

Several works have suggested that the dimensions of the CNCs $(5 \mathrm{~nm}$ diameter $\times 100 \mathrm{~nm}$ length) should allow them to pass easily into the cells of the wood; however, there is also evidence of a filtering effect of the CNCs by the wood, meaning penetration only occurs very close to the surface of the wood [56]. Christensen et al. have shown that chitosan solutions with $\mathrm{M}_{w}$ of $6000-60,000 \mathrm{~g} / \mathrm{mol}$ can penetrate archaeological wood, although the diffusion is significantly improved as the $\mathrm{M}_{w}$ decreases [36]. Despite diffusion into cells, given their molar masses and dimensions with respect to CNCs, it may be difficult for these biopolymers to penetrate the cell wall. Archaeological wood has an average cell wall pore size of 10-20 nm [43], which may explain the filtering effect of the CNCs and may also prevent large polysaccharides from penetrating the cell wall in the same manner as PEG. Thus, further examination of the size vs. structure relationship of these polysaccharides is warranted to enhance the likelihood of cell wall penetration without compromising structural integrity. In general, the results obtained here confirm that CNC and chitosan do diffuse into and coat the wood cells, forming films and network structures to a greater or lesser degree, and density measurements of the wood after treatment and freeze-drying (Figures A2 and A3) suggest there is a filtering effect at play. When wood from the outer edges of an archaeological wood segment was treated with chitosan and CNCs (up to $15 \mathrm{~mm}$ depth) the density of the wood before and after drying was very similar, suggesting some infiltration of the polymer into the wood structure. However, samples deeper into the wood (greater than $30 \mathrm{~mm}$ ) showed that the density of the wood after drying was lower than the untreated wood, indicating shrinkage and improper penetration. These results are similar to results obtained for pure water and are in direct contrast to the data obtained from the PEG400 control, which showed a bulking effect even in samples obtained from $50 \mathrm{~mm}$ into the wood segment, which would be expected to be more dense and more difficult to penetrate.

Alginate, with a molar mass of $100,000 \mathrm{~g} / \mathrm{mol}$, showed a much greater affinity for the wood surface chemistry than either CNCs or chitosan, resulting in a greater degree of coverage of the wood after treatment. By cutting thin samples of the wood, the viscosity contribution was reduced as the treatment does not need to penetrate the entire wood structure, just the open cellular structure. Despite this, it would still be expected that a lower-viscosity solution such as CNCs $\left(1.92 \mathrm{~mm}^{2} / \mathrm{s}\right)$ or chitosan $\left(12.62 \mathrm{~mm}^{2} / \mathrm{s}\right)$ would have less difficulty penetrating all aspects of the wood structure than alginate $\left(68.68 \mathrm{~mm}^{2} / \mathrm{s}\right)$. In addition to their viscosities, these three solutions have significantly different charges, with chitosan being positively charged, CNCs slightly negatively charged, and alginate strongly negatively charged. Janeček et al., noted that surface charge, more than viscosity, affected the diffusion of a variety of polymers aimed at reinforcing lower-grade woods [53]. 
In this work, negatively charged polymer solutions appeared to diffuse better into the wood than positively charged or zwitterionic polymers. It would seem that the same is true in this case. Again referring to the density measurements shown in the Appendix A, Figures A2 and A3, samples obtained from a depth of $30 \mathrm{~mm}$ into the wood showed a higher density after treatment with alginate, similar to the data obtained from PEG400; however this effect was no longer visible in samples obtained from more than $50 \mathrm{~mm}$ into the wood (less than $30 \mathrm{~cm}$ from the inner protected side of the wood, Figure A3), which suggests that charge assists to a certain point but is eventually counteracted by polymer size. With respect to why negatively charged polymers diffuse to a greater extent in wood, it may simply be the case that the negatively charged polymers, containing carboxyl groups, are undergoing esterification reactions with free $\mathrm{OH}$ groups on the wood surface under the acidic conditions present within the wood. This would lead to covalent interactions with the wood in comparison to CNCs and chitosan, which interact through physical interactions. Such variation in the different properties of the polymers in the wood cells as a function of drying and of the type of wood used begs the questions of how dependent structure formation is on the environment and how the films and networks interact with the components of the wood cell wall.

\subsection{Thermal Stability of Fresh and Archaeological Woods as a Function of Treatment}

In order to understand the structuration of the biopolymers within the wood cells, some idea of their interactions with the wood surface was required. To gain this information, thermogravimetric analysis (TGA) was employed. Several publications have highlighted the utility of thermal analysis in understanding the effect of treatment on the natural behaviour of the wood [57-59]. In these works, increases in the maximum pyrolysis temperature (MPT) of the wood were linked to a restorative effect of the treatment, enhancing the ability of the wood to resist thermal degradation. Decreases in MPT were linked to incompatibility and a negative impact of the treatment on the wood. By observing which of the characteristic wood peaks was altered, an understanding of the affinity of the treatments for various cell components could also be obtained.

Figure 5 shows the differential thermograms (DTGs) of fresh and archaeological oak before and after treatment with $0.5 \mathrm{wt}$ \% solutions of chitosan, alginate and CNCs. In Figure 5, there are three principle characteristic peaks in the DTGs of all four control samples, both air- and freeze-dried fresh and archaeological oak: a peak around $275^{\circ} \mathrm{C}$ for the amorphous cellulose and hemicellulose content, which is more pronounced in the fresh wood due to lack of degradation, a peak at $315-330^{\circ} \mathrm{C}$, representing crystalline cellulose and a peak at $405-445^{\circ} \mathrm{C}$, representing lignin. The degree of shifting of the peaks is an indication of the crystallinity or the state of degradation of the component. The negative shift of the lignin peak between fresh and archaeological samples before treatment confirms the observation by Colombini et al. that lignin does not remain unchanged throughout the degradation process [60].

In the chitosan-treated samples, there was no significant shift of the cellulosic peaks after treatment; however, there was a marked difference in the lignin peaks, which shifted from 405 to $450{ }^{\circ} \mathrm{C}$ in the air-dried sample and 410 to $440{ }^{\circ} \mathrm{C}$ in the freeze-dried sample. The shifting of the lignin peak to higher temperatures after treatment suggests interactions of the chitosan with the lignin, improving its thermal properties to pre-degradation values. However, no significant interaction of the chitosan with the cellulosic components was observed. Due to the decreased cellulosic content of the degraded wood, affinity for the lignin skeleton is an important attribute in a consolidant for very degraded wood.

In direct contrast to chitosan-treated samples, CNC-treated samples showed no shift in the lignin peak, and all changes were observed at the cellulosic peaks. In the freeze-dried sample a broadening of the crystalline cellulose peak was observed, while the air-dried sample showed a change in the amorphous peak. It would, therefore, appear that the structuration of the cellulose consolidant has a strong effect on its thermal stability. This correlates with the organisation of the cellulose, or lack thereof, observed in the SEM. Due to 
its chemical structure, CNCs appear to have a greater affinity for the cellulosic component than lignin, which is to be expected. It is also interesting to note that their organisation on the wood surface seems to play a role in the thermal stability of CNC-treated wood.

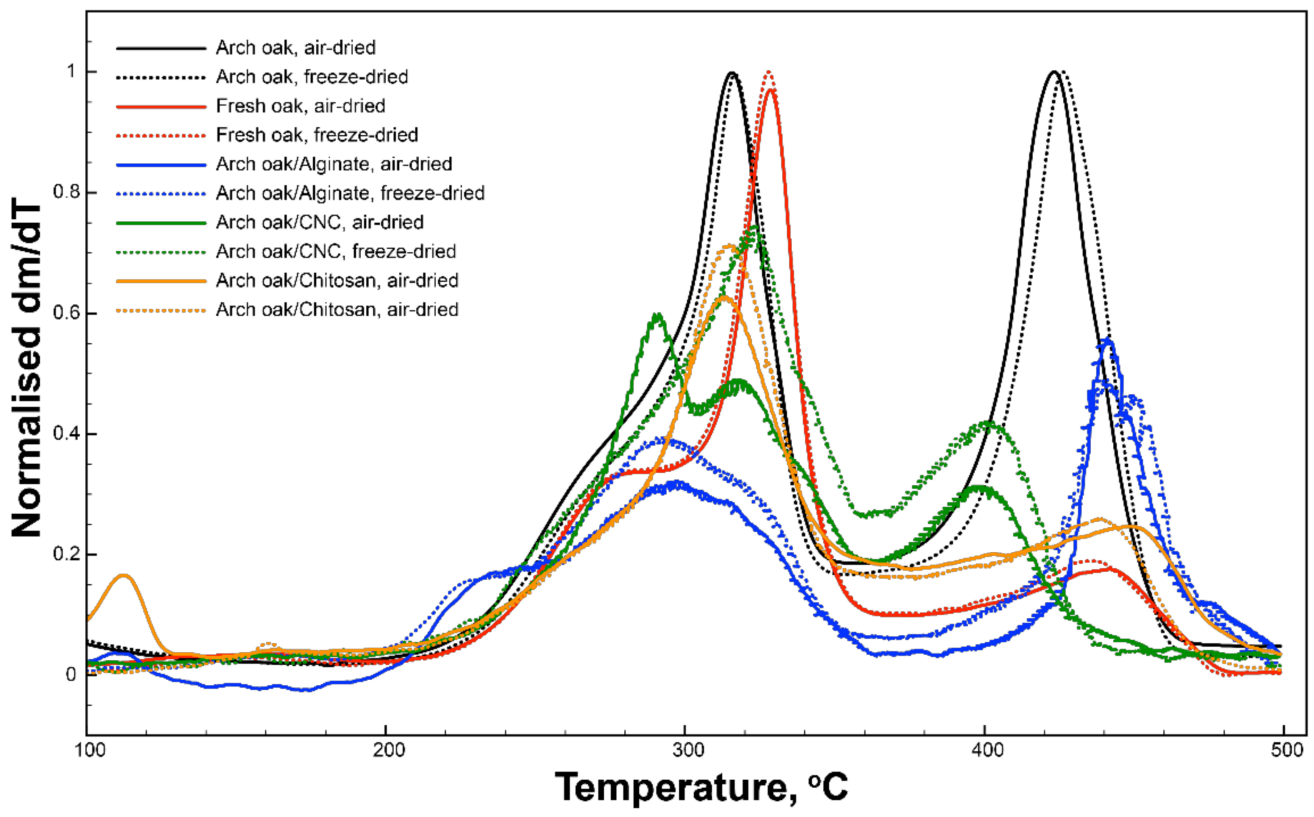

Figure 5. Differential thermograms (DTG) of fresh (red) and archaeological (black) wood before treatment, alginate-treated archaeological wood (blue), CNC-treated archaeological wood (green) and chitosan-treated archaeological wood (orange) after air- and freeze-drying.

Finally, the DTG plots of alginate-treated wood showed that changes in both the lignin and cellulose peaks occurred in these samples. It seems that the extensive wall coating of the more amorphous alginate on the cellulose of the archaeological wood results in a noticeable negative shift in the thermal degradation peak of the crystalline cellulose towards the amorphous cellulose region. This indicates that the addition of alginate to the wood structure reduced the thermal stability of the cellulose. On the contrary, alginate induced a positive shift in the lignin peak from 409 to $442{ }^{\circ} \mathrm{C}$ in both the air- and freezedried samples. As observed with the chitosan-treated wood, after treatment, the alginate returned the lignin peak to a similar value as lignin in fresh wood.

From these results it appears that chitosan interacts solely with the lignin component, and CNCs solely interact with the cellulosic material, while alginate appears to interact with both of the major components. Although alginate appears to reduce the thermal stability of the cellulosic matrix, the reduced prevalence of celluloses in degraded wood mean that this may not always be an issue of high concern in consolidant selection. The results of this thermal study highlight the potential unsuitability of CNCs as an archaeological wood consolidant if the main point of attachment is through cellulose. This issue is visually evident in Figure 4i-1, where the surface coating on the CNC-treated fresh wood samples, as seen in Figure 4i,j, appear much greater than those in Figure 4k,1, which represent the treated archaeological wood.

\subsection{Effect of the Biological Activity of the Polymer}

Initially, the biological activity of chitosan, alginate, CNCs and PEG400 was observed in the presence of untreated archaeological wood over 4 weeks, during a treatment protocol. Although this does not provide quantitative data of anti-microbial activity, it is an indication of the suitability of the polymer for the treatment process without the need to add antimicrobial agents. The results of these observations are shown in Appendix A, Table A1.

While PEG400 has no native anti-bacterial properties, little biological activity was observed in the PEG400 solutions over the course of the treatment. This is likely due to 
the observations reported by Björdal and Nielsen that, above a certain concentration, PEG acts as an oxygen barrier, preventing the growth of aerobic bacteria, thus appearing to limit bacterial growth [61]. In reality, it simply requires more time for the oxygen to penetrate the PEG and allow bacteria and fungi to grow; once exposed they proliferate quite rapidly, forming a biofilm.

For a more quantitative idea of the anti-bacterial properties of the polymers chosen for this study, biological tests were performed as described by Walsh et al. on E. coli in lysogeny broth for $24 \mathrm{~h}$ at $37{ }^{\circ} \mathrm{C}$ [26]. Here, $50 \mathrm{wt}$.\% PEG4000 was also tested in addition to the previously chosen polymers to understand if there was a marked difference in anti-bacterial efficiency as a function of chain length. The results of these tests are shown in Figure 6.

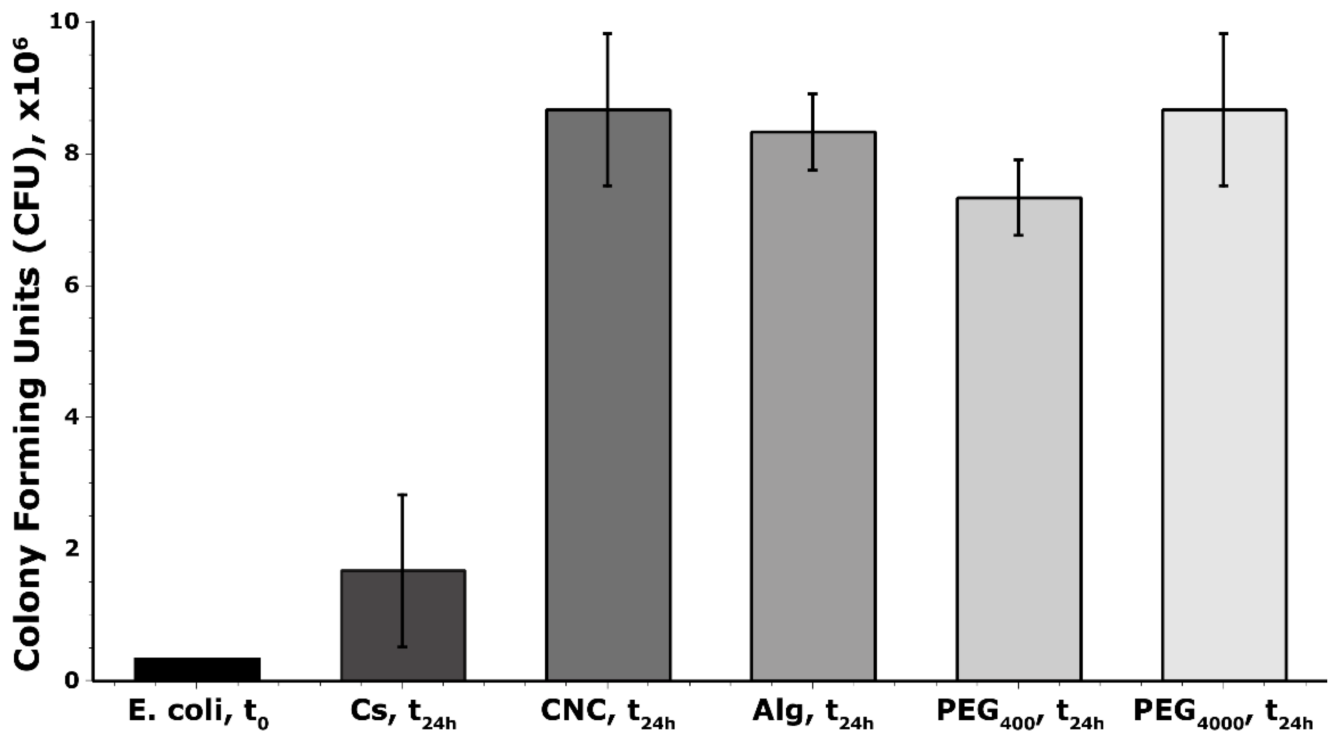

Figure 6. Bar chart showing the number of $E$. coli after $24 \mathrm{~h}$ incubation with chitosan, CNCs, alginate, PEG400 and PEG4000.

As expected from Figure 6 it is clear that, regardless of the observations made in the treatment bath, chitosan is the best treatment option in terms of quantifiable anti-bacterial efficiency. CNCs and alginate do not show significant anti-bacterial properties. Interestingly, PEG4000 and CNCs both offer similarly low resistance to colony formation, followed by alginate and PEG400. Chitosan offered the greatest resistance to bacterial colony formation.

A major question in relation to this work is whether the structure of the polymer formed during drying affects its behaviour as a consolidant material, more specifically if structured polymers are more effective than those without a defined structure. Examples from the natural world, such as duck feathers, cicada wings and nacre, show that the structure of biomaterials often leads to enhanced water repellency, bactericidal properties or mechanical properties, respectively [62-64]. To test whether the chosen polymers can display differences in microbial resistance as a function of organisation, an example of a good and a poor anti-bacterial consolidant were subjected to freeze- and air-drying and then to further testing against E. coli and B. subtilis. As it was evident that chitosan and alginate possess more desirable consolidant qualities than CNCs, as validated by a similar realisation in a recent paper by Antonelli et al. [56], who noted a filtering effect of CNCs when used for archaeological wood conservation, only chitosan and alginate were examined for the rest of the study. Agar plates were prepared, to which cultured E. coli was added. An air-dried film and a freeze-dried foam of both chitosan and alginate were placed on each plate and allowed to incubate overnight at $37^{\circ} \mathrm{C}$. This experiment was repeated in triplicate, and an example of the results shown in Figure A4 of Appendix A.

Figure A4a shows that there was no change in the anti-bacterial behaviour of these polymers as a function of their structure. The freeze-dried polysaccharides were also tested against B. subtilis (Figure A4b,c) with similar results. Regardless of organisation, chitosan 
remains strongly anti-bacterial in the contact region, while alginate is quickly dissolved by the bacterial medium and colonised by the bacteria. This illustrates that, at least in the case of these biopolymers, there is no clear enhancement of bacterial resistance as a function of structure.

\subsection{Sensitivity of the Structuration to Environmental Influences}

A principal question arising from this study, why alginate attaches better to the wood samples than the other biopolymers tested, remains to be answered. Does the enhanced adhesion relate to surface charge or chemistry? Can this supersede viscosity and molar mass in the treatment of wooden objects? Or is the behaviour of the alginate more susceptible to the environment inside the wood, the presence of salts or extractives, which act to enhance the structuration of the alginate polymer? Or is there a combination of different effects?

In order to examine the susceptibility of the consolidants to their environment and the effect on their eventual structure, pieces of archaeological oak approximately $0.5 \mathrm{~cm} \times$ $0.5 \mathrm{~cm} \times 0.5 \mathrm{~cm}$ were added to $1 \mathrm{wt}$.\% solutions of chitosan or alginate and allowed to soak for approximately 14 weeks. After this time the wood was removed, and the solution was diluted 10-fold. A drop of this solution was placed onto freshly cleaned silicon wafers and dried by either air- or freeze-drying; the resulting structures were imaged by SEM and are shown in Figure 7.

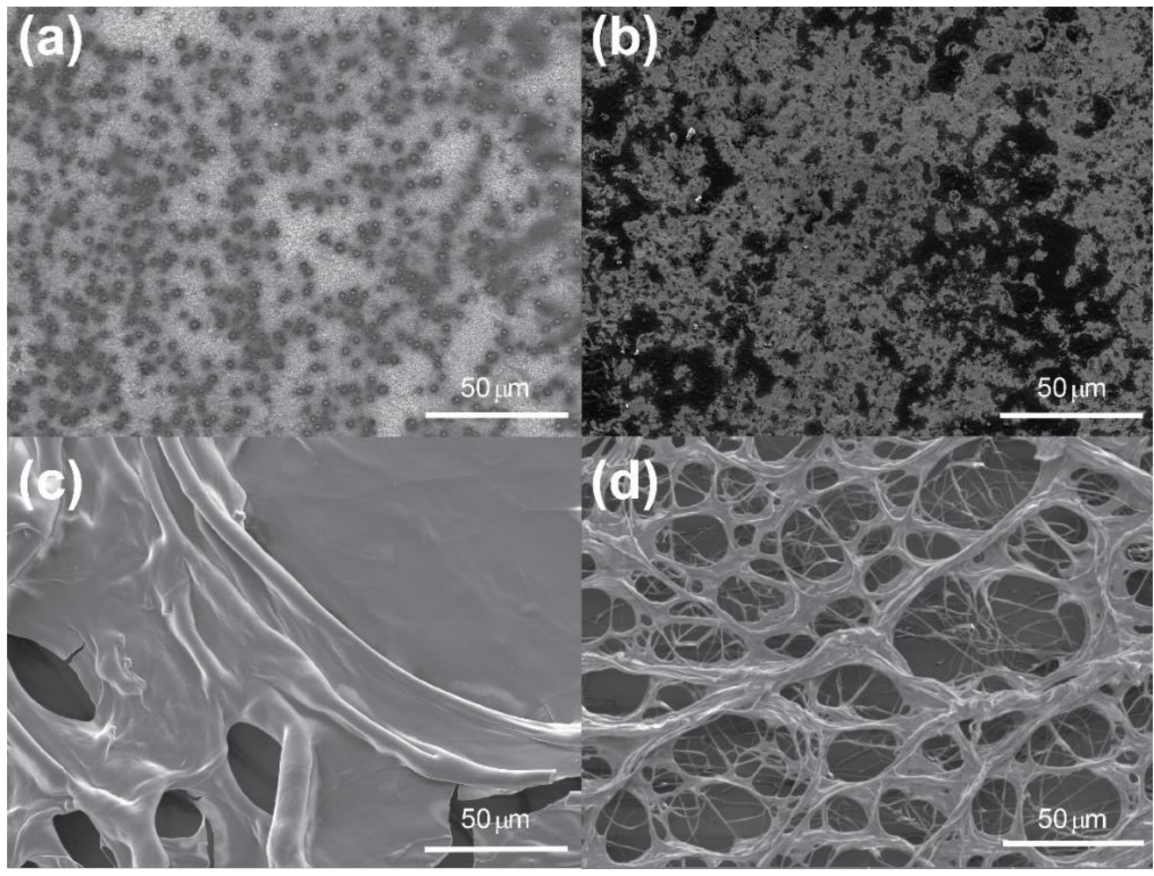

Figure 7. Scanning electron micrographs of air-dried chitosan (a) and alginate (b) and freeze-dried chitosan (c) and alginate (d) in the presence of wood extractives, magnification $1.38 \mathrm{k} \times$.

As with Figure 2a-c, there was no structuration of the air-dried samples, although the crystalline content appeared to be greater. This is likely a result of an increased concentration of salts and sugars present in solution from the wood. The difference in structure in the freeze-dried samples is much more evident. Despite applying a freeze-drying procedure as before, there was no defined structure in the chitosan sample (Figure 7c). The presence of salts and extractives from the archaeological wood appeared to contribute to the loss of the discreet network structure observed in Figure $2 d$, with chitosan now forming a thick film with some larger pores. Alginate, on the other hand, appeared to retain and even improve its network structure as a function of the environment with evidence of fibrillation of chains, as seen in Figure 7d, that cannot be observed in Figure 2e. Such structural motifs are similar to those displayed by proteins such as collagen or fibrin, whose structures are 
linked to their exquisite mechanical properties. The environment of the wood is, however, extremely complex, and further investigation of the interaction of the biopolymers with individual components of the wood will be necessary to properly understand the role of the environment in their behaviour. As a preliminary result, however, such an enhancement in the structuration of alginate is extremely interesting and points to the need for more detailed investigation of alginate as a consolidant material or a base for the design of more responsive consolidants. Given that alginate has long been used in bone repair, another complex environment, with much success, the positive properties of alginate applied to the conservation of wooden materials are not entirely unexpected.

\section{Conclusions}

In this work the biological, morphological and thermal properties of several biopolymertreated wood samples have been investigated for the development of new and efficient consolidants for waterlogged wood. The morphology of the treatments upon drying, how this is affected by the drying protocol and whether this plays a role in the biological resistance or thermal stability of the treated wood was also investigated. It is evident from this work that the drying protocol, and the resulting structure, do not play a key role in the biological resistance of the biopolymer consolidants tested here but may influence the thermal stability of the treated wood. After freeze-drying in the presence of wood extractives, alginate formed a more fibrillated network structure, which may aid the overall dimensional stability of the treated wood. This enhanced structure was absent in the other polymers tested, as well as the air-dried samples, suggesting alginate is more resistant to the effect of sugars and other polymers present in the wood. Both alginate and chitosan appeared to enhance the thermal stability of the lignin component of the treated wood, an important factor in choosing consolidants for archaeological wood where the cellulosic component may be significantly reduced. Thus, the results obtained here suggest that alginate, along with chitosan, are suitable polymers for further development of consolidants for archaeological wood, particularly with respect to freeze-drying. However, a better understanding of the molar mass-3D structure relationship of these polymers must be obtained, alongside development of modification strategies to enhance the microbial resistance of alginate, before systematic studies in archaeological wood can be undertaken. Thus, alginate and chitosan-based consolidants should be, or should continue to be, the focus for future sustainable consolidant development.

Author Contributions: Conceptualisation, Z.W.-K.; methodology, Z.W.-K., I.S. and J.d.S.G.; formal analysis, Z.W.-K., I.S. and J.d.S.G.; investigation, Z.W.-K.; resources, L.A. and G.E.; data curation, Z.W.-K.; writing-original draft preparation, Z.W.-K.; writing-review and editing, all authors; supervision, Z.W.-K. and L.A.; project administration, Z.W.-K.; funding acquisition, Z.W.-K. and L.A. All authors have read and agreed to the published version of the manuscript.

Funding: The research leading to these results has received funding from the People Programme (Marie Curie Actions) of the European Union's 7th Framework Programme (FP7/2007-2013) under REA grant agreement n. PCOFUND-GA- 2013-609102, through the PRESTIGE programme coordinated by Campus France, awarded to Z.W.-K. (PRESTIGE-2016-2-008). Z.W.-K. and L.A. also thank the EU 7th Framework project Synpol (Project No. 311815) for financial support. J.d.S.G. thanks the Brazilian National Council for Scientific and Technological Development (CNPq) (grant number 200672/2015-0) for a graduate fellowship.

Institutional Review Board Statement: Not applicable.

Informed Consent Statement: Not applicable.

Data Availability Statement: Supporting data will be made available here: Z.W.-K., I.S., J.d.S.G., G.E. and L.A. (6 December 2021). Morphological study of bio-based polymers in the consolidation of waterlogged wooden objects. Retrieved from osf.io/8qae4 (accessed on 6 December 2021).

Acknowledgments: The authors thank the Mary Rose Trust for providing samples of fresh and archaeological wood for this study. 
Conflicts of Interest: The authors declare no conflict of interest.

\section{Appendix A}

Appendix A.1. Examination of Freeze-Drying Behaviour In Situ with a Freeze-Drying Microscope

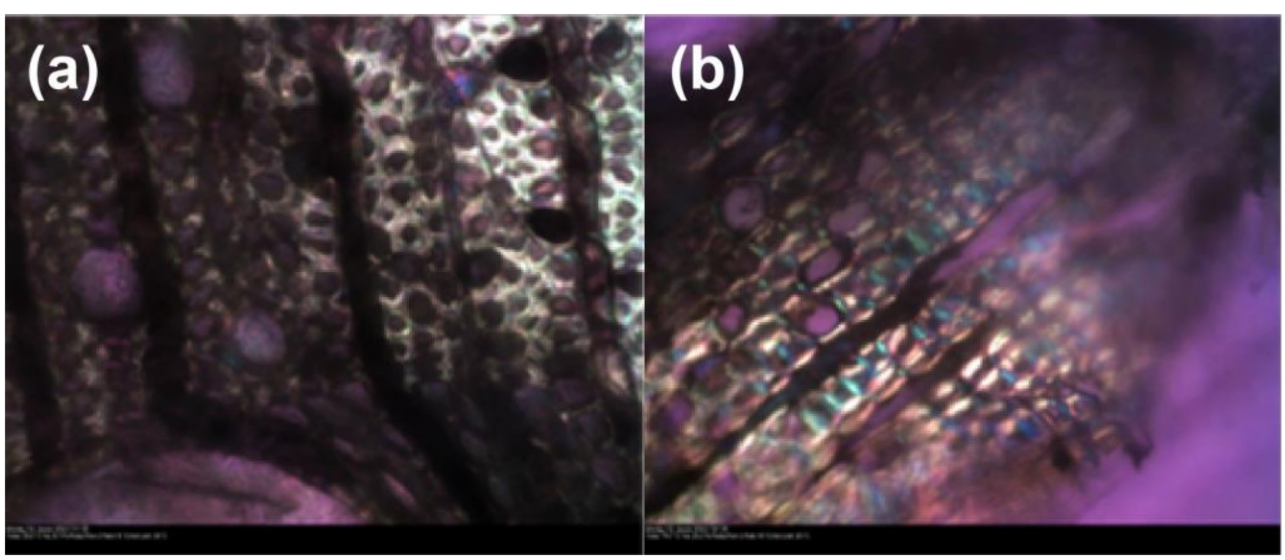

Figure A1. Optical microscope images of the wood with (a) 1 wt.\% chitosan solution and (b) water, magnification $65 \times$.

Appendix A.2. Preparation of Polymer Films for Scanning Electron and Optical Microscopy

Optical microscopy samples were drop-cast on mica surfaces, which were freshly delaminated before deposition. Scanning electron microscopy samples were also drop-cast but on silicon wafers, which were cleaned with piranha solution and then stored in ethanol prior to use. In all cases the biopolymer solutions and PEG were diluted 1000-fold before casting in order to be able to see discrete structures on the sample surface.

\section{Appendix A.3. Treatment of the Wood Samples with Biopolymer Solutions and PEG}

Biopolymer solutions were prepared at a concentration of $0.5 \mathrm{wt} . \%$ while PEG400 was prepared at $50 \mathrm{wt} . \%$ in deionised water. A block approximately $0.8 \mathrm{~cm}$ thick was cut from a piece of waterlogged untreated archaeological wood and then further divided into cubes of approximately $0.8 \times 0.5 \times 0.5 \mathrm{~cm}^{3}$. Each cube was labelled and then placed in a polymer solution and stored in the refrigerator for 14 weeks before drying and weighing. The samples before treatment can be seen in Figure A2.

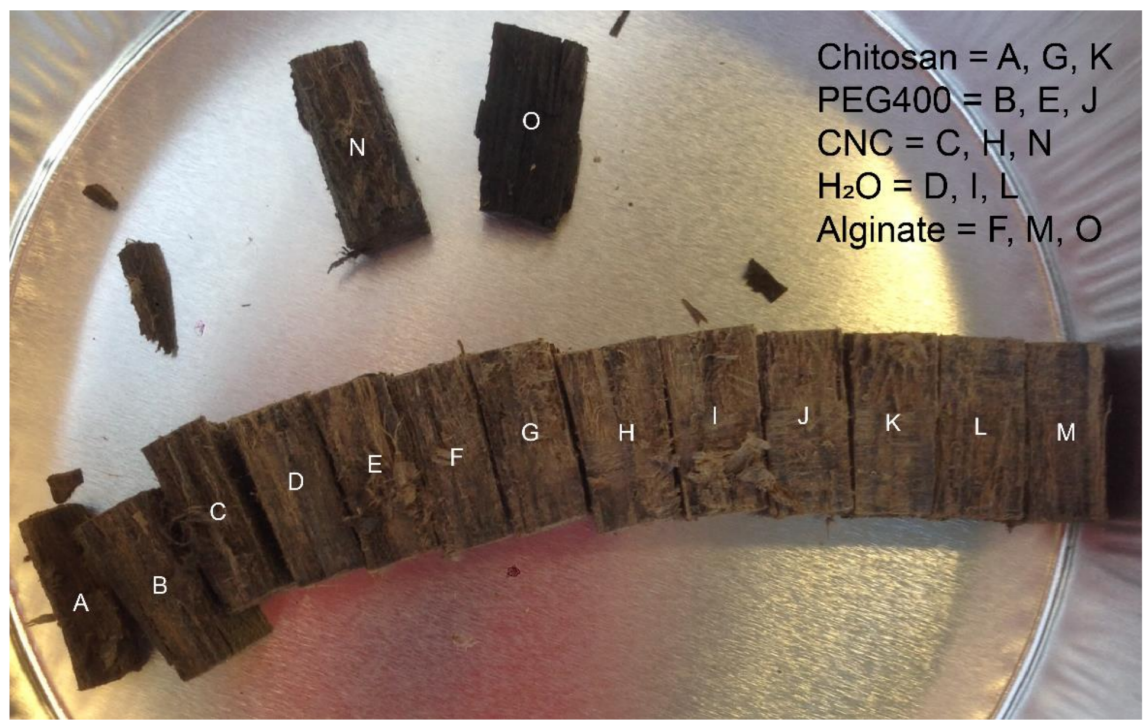

Figure A2. Visual observation of samples of archaeological wood before treatment. 
The dimensions of the samples were measured before and after drying (by lyophilisation) to understand density changes as a function of treatment. Samples were taken from a slice of Mary Rose oak beam and treated with various polymers at different penetration depths, meaning the distance from the outer surface. The order of the samples corresponds to the order seen in Figure A2, where X5 and X10 were the last $5 \mathrm{~mm}(\mathrm{~N}$, Figure A2) and last 5-10 $\mathrm{mm}(\mathrm{O}$, Figure A2) of a second slice to have the same number of samples for each treatment. These would be of equivalent degradation to $\mathrm{L}$ and $\mathrm{M}$, as seen in Figure A2. Penetration of bio-based consolidants was compared to that of pure water and PEG400. The depths in Figure A3 are given as the distance from the outer edge; the samples up to the centre were obtained from the exposed side of the wood, and the samples after the centre were from the inner protected side of the beam; this was estimated to be the denser side of the wood as it was less obviously degraded.

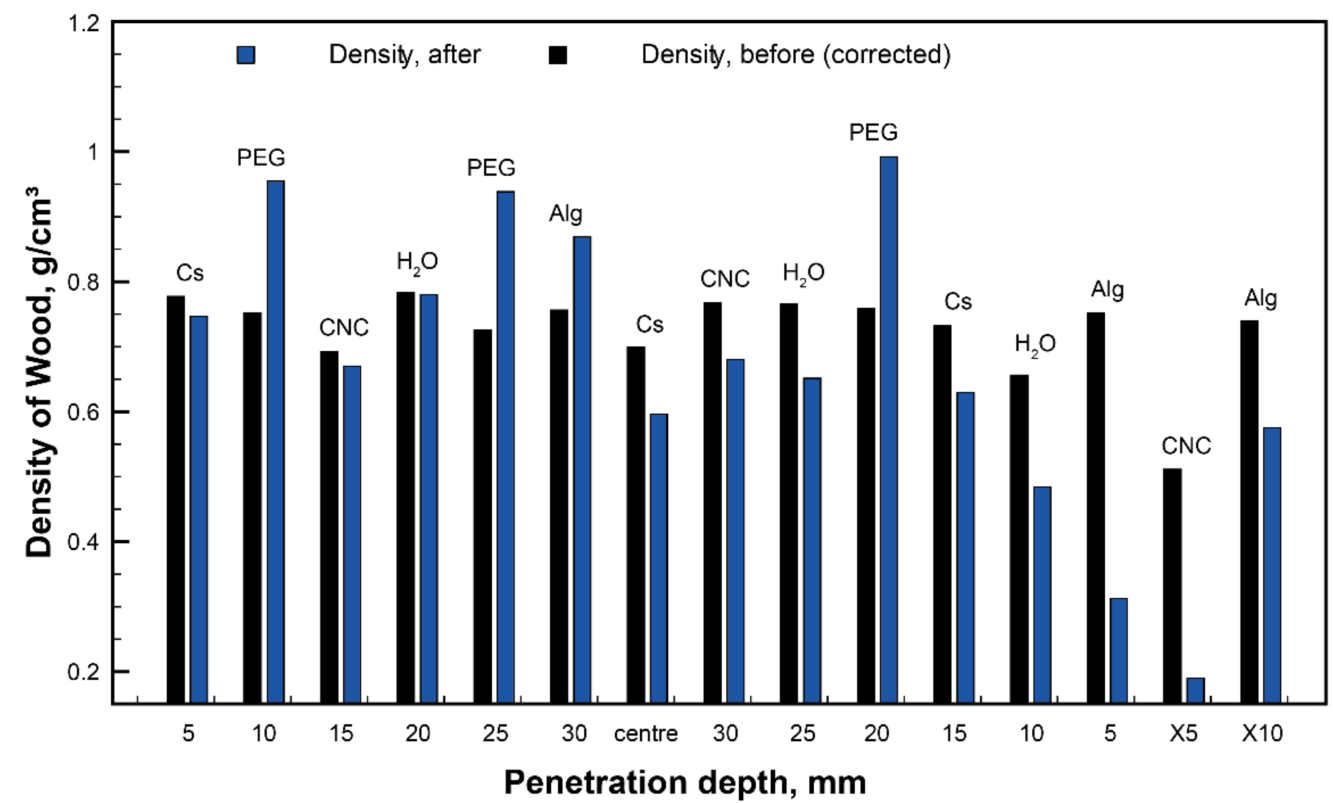

Figure A3. A histogram of the density of the wood samples before treatment, after soaking and after drying as a function of penetration depth and polymer solution, showing the effect of the drying conditions on the density.

\section{Appendix A.4. Visual Observation of Anti-Bacterial Properties of Treatment Solutions}

Table A1. Table of the biological activity observed in the samples during treatment relative to the treatment solutions used; numbering is related to samples seen in Figure A2.

\begin{tabular}{ccc}
\hline Samples & Treatment & Presence and Degree of Biological Activity \\
\hline $1-3$ & $\mathrm{H}_{2} \mathrm{O}$ & $\begin{array}{c}\text { (d) Small bacterial filaments } \\
\text { (i) Mild biological activity } \\
\text { (l) Moderate biological activity }\end{array}$ \\
\hline $4-6$ & 50 wt.\% PEG400 & $\begin{array}{l}\text { (b) Does not sink, no biological activity } \\
\text { (e) Does not sink, no biological activity } \\
\text { (j) Sinks, no biological activity }\end{array}$ \\
\hline $7-9$ & 0.5 wt.\% chitosan & $\begin{array}{l}\text { (a) No biological activity } \\
\text { (g) No biological activity } \\
\text { (k) No biological activity }\end{array}$ \\
\hline
\end{tabular}


Table A1. Cont.

\begin{tabular}{ccc}
\hline Samples & Treatment & Presence and Degree of Biological Activity \\
\hline $10-12$ & 0.5 wt.\% CNCs & $\begin{array}{l}\text { (c) Moderate biological activity } \\
\text { (h) Moderate biological activity } \\
\text { (n) High biological activity }\end{array}$ \\
(f) Low biological activity \\
$15-15$ & $0.5 w t . \%$ alginate & $\begin{array}{l}\text { (m) Mild biological activity } \\
\text { (o) Mild biological activity }\end{array}$ \\
\hline
\end{tabular}

\section{Appendix A.5. Protocols for Biological Testing}

Biological activity within the polymer solutions was tested according to the following procedure adapted from Tan et al. [65]. A total of $1 \mathrm{~mL}$ of the bacterial preculture (E. coli or B. subtilis) was added to $10 \mathrm{~mL}$ of Luria-Bertani lysogeny broth in a $50 \mathrm{~mL}$ Erlenmeyer flask and incubated overnight at $37^{\circ} \mathrm{C}$ while being agitated continuously at $200 \mathrm{rpm}$. After incubation, a solution containing $10^{7} \mathrm{CFU} / \mathrm{mL}$ of microorganism (where optical density at $600 \mathrm{~nm}\left(\mathrm{OD}_{600 \mathrm{~nm}}\right)=0.01$ to E. coli) was prepared. Into each well of a multiwell plate (tissue culture plate, 24 well) $200 \mu \mathrm{L}$ of the bacterial suspension containing $10^{7}$ cells $/ \mathrm{mL}, 1 \mathrm{~mL}$ of fresh $\mathrm{LB}$ and $1 \mathrm{~mL}$ of the polymer solutions $(0.5 \mathrm{wt} . \%$ for the biopolymer or $10 \mathrm{wt} . \%$ for PEG) were added. In order to minimise contamination of the samples 6 individual samples with three replicates were prepared for every polymer solution so that repeated sampling of the solutions would not be necessary to monitor bacterial growth over time. Once prepared the initial $\mathrm{OD}_{600 \mathrm{~nm}}$ of the solutions was measured and the 1st row of solutions discarded. The multiwell plate was then returned to the incubator and agitated at $200 \mathrm{rpm}$ and $37^{\circ} \mathrm{C}$. The plates were removed and the $\mathrm{OD}_{600 \mathrm{~nm}}$ measured in triplicate every $2 \mathrm{~h}$ until $8 \mathrm{~h}$, and then samples were taken again at $24 \mathrm{~h}$. The inhibitory index of the samples can then be calculated from the following Equation:

$$
\text { Inhibitoryindex }(\%)=\left[1-\left(\frac{A_{\text {sample } 600 \mathrm{~nm}}-A_{\text {sample } 0600 \mathrm{~nm}}}{A_{\text {reference } 600 \mathrm{~nm}}-A_{\text {reference } 0600 \mathrm{~nm}}}\right)\right] \times 100
$$

where $A_{\text {sample } 600 \mathrm{~nm}}$ is the absorbance of bacterial medium with sample after incubation, $A_{\text {sample } 0600 \mathrm{~nm}}$ is the absorbance of bacterial medium with sample before incubation, $A_{\text {reference } 600 \mathrm{~nm}}$ is the absorbance of bacterial medium after incubation, and $A_{\text {reference } 0600 \mathrm{~nm}}$ is the absorbance of bacterial medium before incubation.

\section{Appendix A.6. Testing the Effect of the Biological Activity of the Polymer}

Agar plates were prepared, to which cultured E. coli was added. On each plate an airdried film and a freeze-dried foam of both chitosan and alginate were placed and allowed to incubate overnight at $37^{\circ} \mathrm{C}$ in the static incubator. This experiment was repeated in triplicate, and an example of the results shown in Figure A4.

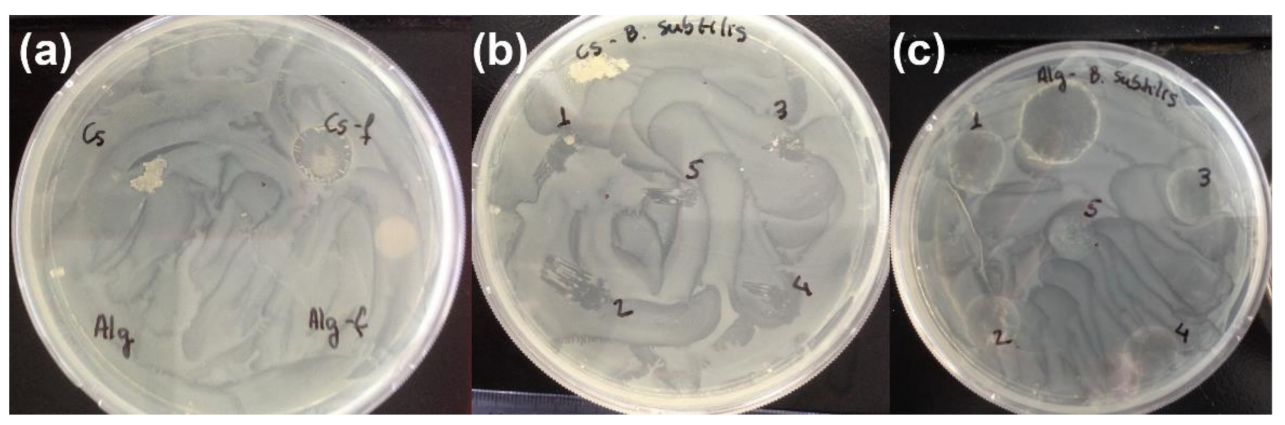

Figure A4. Photographs of biological resistance tests of (a) freeze-dried and air-dried chitosan and alginate against E. coli, (b) freeze-dried chitosan and (c) freeze-dried alginate against B. subtilis. 


\section{References}

1. Kibblewhite, M.; Tóth, G.; Hermann, T. Predicting the preservation of cultural artefacts and buried materials in soil. Sci. Total Environ. 2015, 529, 249-263. [CrossRef]

2. Rowell, R.M.; Barbour, R.J. Preface. In Archaeological Wood: Properties, Chemistry, and Preservation; Rowell, R.M., Barbour, R.J., Eds.; American Chemical Society: Washington, DC, USA, 1989; pp. xi-xii.

3. Menotti, F. Wetland Archaeology and Beyond: Theory and Practice; Oxford University Press: Oxford, UK, 2012.

4. Bjurhager, I.; Halonen, H.; Lindfors, E.-L.; Iversen, T.; Almkvist, G.; Gamstedt, E.K.; Berglund, L.A. State of degradation in archeological oak from the 17th century Vasa ship: Substantial strength loss correlates with reduction in (holo)cellulose molecular weight. Biomacromolecules 2012, 13, 2521-2527. [CrossRef]

5. Schlichtherle, H. Die jungsteinzeitlichen Radfunde vom Federsee und ihre kulturgeschichtliche Bedeutung. In Schleife, Schlitten, Rad und Wagen Zur Frage Früher Transportmittel Nördlich der Alpen; Könninger, J., Mainberger, M., Schlichtherle, H., Vosteen, M., Eds.; Landesamt für Denkmalpflege/Janus Verlag: Freiburg im Breisgau, Germany, 2002; pp. 9-34.

6. Bell, L.S.; Lee Thorp, J.A.; Elkerton, A. The sinking of the Mary Rose warship: A medieval mystery solved? J. Archaeol. Sci. 2009, 36, 166-173. [CrossRef]

7. Giachi, G.; Bettazzi, F.; Chimichi, S.; Staccioli, G. Chemical characterisation of degraded wood in ships discovered in a recent excavation of the Etruscan and Roman harbour of Pisa. J. Cult. Herit. 2003, 4, 75-83. [CrossRef]

8. Bjurhager, I.; Vorobyev, A.; Van Dijk, N.; Gamstedt, E.K.; Ahlgren, A.; Olofsson, M. Investigation of time-dependent deformation of wood from the warship Vasa. In Proceedings of the 12th ICOM-CC Wet Organic Archaeological Materials Conference, Istanbul, Turkey, 13-17 May 2013. Available online: http:/ / uu.diva-portal.org/smash/record.jsf?pid=diva2\%3A666233\&dswid=-405 (accessed on 2 December 2021).

9. Hamilton, D.L. Methods for Conserving Archaeological Material from Underwater Sites. Available online: https://nautarch. tamu.edu/CRL/ conservationmanual/ConservationManual.pdf (accessed on 2 December 2021).

10. Fors, Y.; Sandström, M. Sulfur and iron in shipwrecks cause conservation concerns. Chem. Soc. Rev. 2006, 35, 399-415. [CrossRef]

11. Blanchette, R.A. A review of microbial deterioration found in archaeological wood from different environments. Int. Biodeterior. Biodegrad. 2000, 46, 189-204. [CrossRef]

12. Kim, Y.S.; Singh, A.P. Micromorphological Characteristics of Wood Biodegradation in Wet Environments: A Review. IAWA J. 2000, 21, 135-155. [CrossRef]

13. Pedersen, N.B. Microscopic and Spectroscopic Characterisation of Waterlogged Archaeological Softwood from Anoxic Environments. Ph.D. Thesis, University of Copenhagen, Copenhagen, Denmark, 2014.

14. Jensen, P.; Strætkvern, K.; Schnell, U.; Jensen, J.B. Technical specifications for equipment for vacuum freeze-drying of PEG impregnated waterlogged organic materials. In Proceedings of the 10th ICOM Group on Wet Organic Archaeological Materials Conference, Amsterdam, The Netherlands, 10-15 September 2007; Strætkvern, K., Huisman, D.J., Eds.; Nederlandse Archeologische Rapporten: NAR, 37. Rijksdienst voor Archeologie, Cultuurlandschap en Monumenten: Amersfoort, The Netherlands, 2009; pp. 417-438.

15. Hoffmann, P. Conservation of Archaeological Ships and Boats-Personal Experiences; Archetype Publications: London, UK, 2013.

16. Jensen, P.; Bojesen-Koefoed, I.; Meyer, I.; Strætkvern, K. The cellosolve-petroleum method. In Proceedings of the 5th ICOM Group on Wet Organic Archaeological Materials conference, Portland, Maine, 16-20 August 1993; Hoffmann, P., Daley, T.W., Grant, T., Eds.; Working Group on Wet Organic Archaeological Materials: Bremerhaven, Germany, 1994; pp. 523-532.

17. Jensen, P.; Gregory, D.J. Selected physical parameters to characterize the state of preservation of waterlogged archaeological wood: A practical guide for their determination. J. Archaeol. Sci. 2006, 33, 551-559. [CrossRef]

18. Jones, S.P.P.; Slater, N.K.H.; Jones, M.; Ward, K.; Smith, A.D. Investigating the processes necessary for satisfactory freeze-drying of waterlogged archaeological wood. J. Archaeol. Sci. 2009, 36, 2177-2183. [CrossRef]

19. Schindelholz, E.; Blanchette, R.; Held, B.; Jurgens, J.; Cook, D.; Drews, M.; Hand, S.; Seifert, B. An Evaluation of Supercritical Drying and PEG/Freeze Drying of Waterlogged Archaeological Wood. In Proceedings of the 10th ICOM Group on Wet Organic Archaeological Materials Conference, Amsterdam, The Netherlands, 10-15 September 2007; Strœtkvern, K., Huisman, D.J., Eds.; Nederlandse Archeologische Rapporten: NAR, 37. Rijksdienst voor Archeologie Cultuurlandschap en Monumenten: Amersfoort, The Netherlands, 2009; pp. 399-416.

20. Sanya, E.A.; Rezzoug, S.-A.; Allaf, K. A New Method for Drying Waterlogged Wooden Artefacts: Comparison of Cyclical Pressure Drops with Conventional Methods. Chem. Eng. Res. Des. 2003, 81, 1243-1249. [CrossRef]

21. Mortensen, M.N.; Egsgaard, H.; Hvilsted, S.; Shashoua, Y.; Glastrup, J. Characterisation of the polyethylene glycol impregnation of the Swedish warship Vasa and one of the Danish Skuldelev Viking ships. J. Archaeol. Sci. 2007, 34, 1211-1218. [CrossRef]

22. Graves, D.J. A comparative study of consolidants for waterlogged wood: Polyethylene glycol, sucrose and silicon oil. SSCR J. News Mag. Scott. Soc. Conserv. Restor. 2004, 15, 13-17.

23. Almkvist, G.; Persson, I. Degradation of polyethylene glycol and hemicellulose in the Vasa. Holzforschung 2008, 62, 64-70. [CrossRef]

24. Almkvist, G.; Persson, I. Fenton-induced degradation of polyethylene glycol and oak holocellulose. A model experiment in comparison to changes observed in conserved waterlogged wood. Holzforschung 2008, 62, 704-708. [CrossRef]

25. Lechner, T.; Bjurhager, I.; Kliger, R.I. Strategy for developing a future support system for the Vasawarship and evaluating its mechanical properties. Herit. Sci. 2013, 1, 35. [CrossRef] 
26. Walsh, Z.; Janeček, E.-R.; Hodgkinson, J.; Sedlmair, J.; Koutsioumpas, A.; Spring, D.; Welch, M.; Hirschmugl, C.J.; Toprakcioglu, C.; Nitschke, J.; et al. Multifunctional supramolecular polymer networks as next-generation consolidants for archaeological wood conservation. Proc. Natl. Acad. Sci. USA 2014, 111, 17743-17748. [CrossRef]

27. Walsh, Z.; Janeček, E.-R.; Jones, M.; Scherman, O.A. Natural polymers as alternative consolidants for the preservation of waterlogged archaeological wood. Stud. Conserv. 2017, 62, 173-183. [CrossRef]

28. Bardet, M.; Foray, M.F.; Trân, Q.-K. High-resolution solid-state CPMAS NMR study of archaeological woods. Anal. Chem. 2002, 74, 4386-4390. [CrossRef]

29. Bardet, M.; Gerbaud, G.; Trân, Q.-K.; Hediger, S. Study of interactions between polyethylene glycol and archaeological wood components by 13C high-resolution solid-state CP-MAS NMR. J. Archaeol. Sci. 2007, 34, 1670-1676. [CrossRef]

30. Bardet, M.; Gerbaud, G.; Doan, C.; Giffard, M.; Hediger, S.; De Paëpe, G.; Trân, Q.-K. Dynamics property recovery of archaeologicalwood fibers treated with polyethylene glycol demonstrated by high-resolution solid-state NMR. Cellulose 2012, 19, 1537-1545. [CrossRef]

31. Vorobyev, A.; Van Dijk, N.P.; Kristofer Gamstedt, E. Orthotropic creep in polyethylene glycol impregnated archaeological oak from the Vasa ship. Mech. Time Depend. Mater. 2019, 23, 35-52. [CrossRef]

32. Cipriani, G.; Salvini, A.; Baglioni, P.; Bucciarelli, E. Cellulose as a renewable resource for the synthesis of wood consolidants. J Appl. Polym. Sci. 2010, 118, 2939-2950. [CrossRef]

33. Cipriani, G.; Salvini, A.; Fioravanti, M.; Di Giulio, G.; Malavolti, M. Synthesis of hydroxylated oligoamides for their use in wood conservation. J. Appl. Polym. Sci. 2013, 127, 420-431. [CrossRef]

34. Christensen, M.; Kutzke, H.; Hansen, F.K. New materials used for the consolidation of archaeological wood-past attempts, present struggles, and future requirements. J. Cult. Herit. 2012, 13, S183-S190. [CrossRef]

35. Christensen, M. Developing New Consolidants for Archaeological Wood. Ph.D. Thesis, University of Oslo, Oslo, Norway, 2013.

36. Christensen, M.; Larnøy, E.; Kutzke, H.; Hansen, F.K. Treatment of Waterlogged Archaeological Wood Using Chitosan- and Modified Chitosan Solutions. Part 1: Chemical Compatibility and Microstructure. J. Am. Inst. Conserv. 2015, 54, 3-13. [CrossRef]

37. Walsh-Korb, Z.; Janeček, E.R.; Jones, M.; Averous, L. New Consolidants for the Conservation of Archeological Wood. In Heritage Wood; Springer: Cham, Switzerland, 2019. Available online: https://link.springer.com/chapter/10.1007/978-3-030-11054-3_3 (accessed on 2 December 2021).

38. Vert, M.; Doi, Y.; Hellwich, K.-H.; Hess, M.; Hodge, P.; Kubisa, P.; Rinaudo, M.; Schué, F. Terminology for biorelated polymers and applications (IUPAC Recommendations 2012). J. Macromol. Sci. Part A Pure Appl. Chem. 2012, 84, 377-410. [CrossRef]

39. Wiesner, I.; Gieseler, H. Freeze Dry Microscopy: Real-Time Observation of the Drying Process. In Proceedings of the 12th ICOM-CC Group on Wet Organic Archaeological Materials Conference, Istanbul, Turkey, 13-17 May 2013; Grant, T., Cook, C., Eds.; ICOM Committee for Conservation, Working Group on Wet Organic Archaeological Materials: Helsinki, Finland, 2016; pp. 417-424.

40. Wiesner, I.; Beirowski, J. A neolithic shoe from Sipplingen: Technological examination and conservation. In Proceedings of the 11th ICOM-CC Group on Wet Organic Archaeological Materials Conference, Greenville, SC, USA, 2010; Strætkvern, K., Williams, E., Eds.; ICOM Committee for Conservation, Working Group on Wet Organic Archaeological Materials: Helsinki, Finland, 2010; pp. 531-542.

41. Hoffmann, P.; Riens, R.; Eckstein, D. Zur Gefriertrocknung schwer zu konservierender Naßhölzer. Arb. Restaur. 1991, 1, 139-205.

42. Jensen, P.; Jørgensen, G.; Schnell, U. Dynamic LV-SEM analyses of freeze drying processes for waterlogged wood. In Proceedings of the 8th ICOM Group on Wet Organic Archaeological Materials Conference, Stockholm, Sweden, 2001; Hoffmann, P., Spriggs, J.A., Grant, T., Cook, C., Recht, A., Eds.; ICOM Committee for Conservation, Working Group on Wet Organic Archaeological Materials: Bremerhaven, Germany, 2002; pp. 319-333.

43. Broda, M.; Curling, S.F.; Frankowski, M. The effect of the drying method on the cell wall structure and sorption properties of waterlogged archaeological wood. Wood Sci. Technol. 2021, 55, 971-989. [CrossRef]

44. Lipkowitz, G.; Hennum, K.S.; Piva, E.; Schofield, E. Numerical Modelling of Moisture Loss during Controlled Drying of Marine Archaeological Wood. Forests 2021, 12, 1662. [CrossRef]

45. Hennum-Simmonds, K.S. A Study of Alternatives to Freeze-Drying. Master's Thesis, University of Oslo, Oslo, Norway, 2020.

46. Giachi, G.; Capretti, C.; Macchioni, N.; Pizzo, B.; Donato, I.D. A methodological approach in the evaluation of the efficacy of treatments for the dimensional stabilisation of waterlogged archaeological wood. J. Cult. Herit. 2010, 11, 91-101. [CrossRef]

47. Peacock, E. Freeze-drying archaeological textiles: The need for basic research. In Archaeological Textiles, Occasional Papers 10; O'Connor, S.A., Brooks, M.M., Eds.; Institute for Conservation: London, UK, 1990; pp. 22-30.

48. Stelzner, I. Bestimmung Prozessrelevanter Eigenschaften für die Gefriertrocknung in der Nassholzkonservierung. Ph.D. Thesis, Staatliche Akademie der Bildenden Künste, Stuttgart, Germany, 2017.

49. Unger, A. Holzkonservierung: Schutz und Festigung von Holzobjekten; Callwey Verlag: München, Germany, 1990.

50. Meyers, M.A.; Chen, P.-Y.; Lin, A.Y.-M.; Seki, Y. Biological materials: Structure and mechanical properties. Prog. Mater. Sci. 2008, 53, 1-206. [CrossRef]

51. Svagan, A.J.; Samir, M.A.S.A.; Berglund, L.A. Biomimetic foams of high mechanical performance based on nanostructured cell walls reinforced by native cellulose nanofibrils. Adv. Mater. 2008, 20, 1263-1269. [CrossRef] 
52. Gregory, D.J.; Shashoua, Y.; Hansen, N.B.; Jensen, P. Anyone for a nice cup of tea?: The use of bacterial cellulose for conservation of waterlogged archaeological wood. In Proceedings of the ICOM-CC 18th Triennial Conference Preprints, Copenhagen, Denmark, 4-7 September 2017; Bridgland, J., Ed.; ICOM: Paris, France, 2017.

53. Janeček, E.R.; Walsh-Korb, Z.; Bargigia, I.; Farina, A. Time-resolved laser spectroscopy for the in situ characterization of methacrylate monomer flow within spruce. Wood Sci. Technol. 2017, 51, 227-242. [CrossRef]

54. Schnell, U.; Jensen, P. Determination of Maximum Freeze Drying Temperature for PEG-Impregnated Archaeological Wood. Stud. Conserv. 2007, 52, 50-58. [CrossRef]

55. Wegst, U.G.K.; Bai, H.; Saiz, E.; Tomsia, A.P.; Ritchie, R.O. Bioinspired structural materials. Nat. Mater. 2015, 14, 23-36. [CrossRef]

56. Antonelli, F.; Galotta, G.; Sidoti, G.; Zikeli, F.; Nisi, R.; Petriaggi, B.D.; Romagnoli, M. Cellulose and Lignin Nano-Scale Consolidants for Waterlogged Archaeological Wood. Front Chem. 2020, 8, 32. [CrossRef]

57. Soares, S.; Camino, G.; Levchik, S. Comparative study of the thermal decomposition of pure cellulose and pulp paper. Polym. Degrad. Stab. 1995, 49, 275-283. [CrossRef]

58. Sandu, I.C.A.; Brebu, M.; Luca, C.; Sandu, I.; Vasile, C. Thermogravimetric study on the ageing of lime wood supports of old paintings. Polym. Degrad. Stab. 2003, 80, 83-91. [CrossRef]

59. Giorgi, R.; Chelazzi, D.; Baglioni, P. Nanoparticles of calcium hydroxide for wood conservation. The deacidification of the Vasa warship. Langmuir 2005, 21, 10743-10748. [CrossRef]

60. Colombini, M.P.; Lucejko, J.J.; Modugno, F.; Orlandi, M.; Tolppa, E.-L.; Zoia, L. A multi-analytical study of degradation of lignin in archaeological waterlogged wood. Talanta 2009, 80, 61-70. [CrossRef]

61. Björdal, C.G.; Nilsson, T. Observations on microbial growth during conservation treatment of waterlogged archaeological wood. Stud. Conserv. 2001, 46, 211-220. [CrossRef]

62. Pogodin, S.; Hasan, J.; Baulin, V.A.; Webb, H.K.; Truong, V.K.; Nguyen, T.H.P.; Boshkovikj, V.; Fluke, C.J.; Watson, G.S.; Watson, J.; et al. Biophysical model of bacterial cell interactions with nanopatterned cicada wing surfaces. Biophys. J. 2013, 104, 835-840. [CrossRef]

63. Sun, J.; Bhushan, B. Hierarchical structure and mechanical properties of nacre: A review. RSC Adv. 2012, 2, 7617-7632. [CrossRef]

64. Liu, Y.; Chen, X.; Xin, J.H. Hydrophobic duck feathers and their simulation on textile substrates for water repellent treatment. Bioinspir. Biomim. 2008, 3, 046007. [CrossRef]

65. Tan, W.; Li, Q.; Wang, H.; Liu, Y.; Zhang, J.; Dong, F.; Guo, Z. Synthesis, characterization, and antibacterial property of novel starch derivatives with 1,2,3-triazole. Carbohydr. Polym. 2016, 142, 1-7. [CrossRef] 